\title{
VERNACULAR ARCHITECTURE AND TRADITIONAL URBANISM IN THE WORLD HERITAGE CULTURAL LANDSCAPE PROPERTY OF PICO, IN AZORES (PORTUGAL)
}

\author{
R. Florentino ${ }^{1, *}$, M. Correia $^{1}$, G. Sousa ${ }^{1}$, G. Carlos $^{1}$ \\ ${ }^{1}$ CI-ESG, Centro de Investigação, Escola Superior Gallaecia, Largo das Oliveiras 4920-251 Vila Nova de Cerveira, Portugal - \\ (ruiflorentino, marianacorreia, goretisousa, gilbertocarlos)@esg.pt
}

Commission II - WG II/8

KEY WORDS: Vernacular Architecture, Traditional Urbanism, Cultural Landscape, World Heritage, Pico, Azores

\begin{abstract}
:
The World Heritage Committee lists every year, several cultural sites as World Heritage properties. Some of these properties balance the notion of a landscape that bears combined works between nature and men, on which vernacular architecture is part of a local tradition of interaction with nature. The 3dPast research project is a European project, coordinated by Escola Superior Gallaecia and co-funded by the European Union, under the Creative Europe programme. The project studies and values vernacular knowledge of these unique places. In Portugal, the Pico landscape was listed as a World Heritage property due to the 500 years of history of local inhabitants adapting farming practices to produce wine, in a challenge environment and in a remote place in the middle of the Atlantic. This article aims to study, the history and the development of the island's architecture and urbanism, based on an ancestral way of life that is still alive nowadays. The scarcity of natural resources and the difficulties to travel between villages and islands emphasised the effects of insularity. However, the continuity of local culture, passed down through generations, created a strong identity, which is source of pride. The cultural landscape classified area includes about 987 hectares, from the parish of Criação Velha, on the south coast, to Santa Luzia, on the north side, covering part of two municipalities of Pico. The article first presents a brief historical background of the island. Following, it focuses on the evolution of human occupation, through the reading of population indicators and traditional architecture and urbanism, recognizing the unique cultural and landscape values within the property. Finally, it discusses the current regulatory framework on territorial planning, and the architectural and urban regulations in planning framework, with particular emphasis on processes and practices at different scales.
\end{abstract}

\section{INTRODUCTION}

The discovery of the Azores archipelago happened between 1431 and 1466, a decade after Madeira archipelago, Portuguese Islands also in the Atlantic Ocean. The first Azores islands to be found by Portuguese navigators were Santa Maria and São Miguel, in the eastern side. The archipelago is formed by nine Islands, which have a largest distance of around $750 \mathrm{kms}$, a half of the closest point to continental Europe. They were all inhabited. In the opposite western side of the Azores, Pico Island was the seventh to be discovered, before Flores and Corvo islands. Its name was given by the pyramidal form of his mountain, which is a geological volcano that reaches 2.351 meters, the highest mountain in Portuguese territory. For the harbour captaincy of both Pico and Faial Islands, the king D. João II named Joz Van Huester (Jorge d'Ultra). The settlement chosen for the captaincy was Horta, in Faial, a decision that affected the Pico political and economic dependency from Faial Island until the 19th century (Macedo, 1981).

In the beginning of the 16th century, the first place where people settled in Pico, was called named Lajes, due to the black stones of Pico volcano. Lajes is located in the southern part of Pico island, where the land was appropriate for basic agricultural and where it was even possible to extract some fresh water. The second village founded in Pico was São Roque, in 1542, in the northern side of the Island. The protected cultural landscape area starts slightly to the west of São Roque, in Santana, and extends until Pontinha, through 15 rural clusters. It is in this area that wineries were planted in small and irregular plots, protected from the weather conditions by small and handmade stone walls. This was a huge improvement for the economic and social well fare of the population. The third village, Madalena, was established in 1723. It is nowadays, the main villa of Pico, located in the middle of its cultural landscape. It benefits from being the nearest to Faial island, from where the ships arrived, crossing the "channel", well known by the Portuguese literature (Nemésio, 1944).

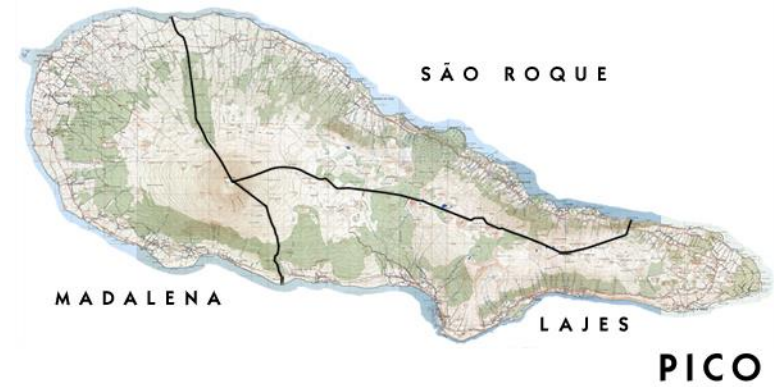

Figure 1. The three municipalities united in the Volcano. Source: Inventário do Património Imóvel dos Açores.

In 1867, Pico reached around 27.000 inhabitants, but the wine agricultural plagues, in the middle of 19th century stopped its development. Part of the population had to emigrate to the United States of America and others join the international whale fishing industry. The wine clusters were abandoned during most of the last century and the growth only started again with the national and regional political changes, after 1974, after the fascist government fell.

\footnotetext{
* Corresponding author
} 
The successful application for a Cultural Landscape World Heritage, in 2004, was the driver for a second stage of development. The classified areas include 987 ha. of a protected site, from the parishes of Criação Velha, in the south coast, to Santa Luzia, in the north one. In the last years, the regional government opened financial support to the land owners, in order to maintain the wine production, through traditional agricultural activities. The Pico Island has now approximately 14.000 inhabitants. The World Heritage status, the Azores Geopark and the subaquatic protected area brought a highquality brand, associated with island. As a result, quality tourism increased. This was certainly relevant for the living and the sustainable approach endured by Pico inhabitants when addressing the protection of the island cultural landscape.

The 3dPast project - Living \& virtual visiting European World Heritage was coordinated by Ci-ESG, the Research Center of esGallaecia/ Escola Superior Gallaecia (Portugal), in partnership with UPV/ Universitat Politècnica de València (Spain) and UNIFI/ Università degli Studi di Firenze (Italy). 3dPast was developed in the framework of the Creative Europe programme, and aims to contribute to the enhancement of vernacular heritage, in particular inhabited World Heritage properties. The project researches the elements that constitute vernacular architecture, in order to enhance the quality of its fabric, to understand cultural spaces and their evolution, through the potential associated with regional heritage, including the territorial component. Methodologically, it makes a comparative and multidisciplinary analysis of different European cases, based on the historical, architectural and intangible dimensions, which can be disseminated using communication tools based on virtual reality and augmented reality technologies. The work developed by the three universities, partners of the European project uses didactic and interactive communication tools, which helps understand these three dimensions in an integrated way, as well as the correlations that are established between them (www.esg.pt/3dpast).

This article aims to contribute to a better understanding of this Portuguese case study: The Cultural Landscape of Ilha do Pico. The paper addresses the reasons why vernacular architecture and traditional urbanism were kept over time. This might help improve the strategies for safeguarding and conserving this heritage, reinforcing the ties of cultural identity, and simultaneously promoting sustainable tourism.

To be considered a World Heritage cultural landscape, it is required that a local management system supports the preservation of the property. This management plan considers the regional strategies for social and economic development integrated in the Master plan; but focus especially on the preservation of the property regarding its Outstanding Universal Value, its authenticity, its integrity and its site protective legislation; as well as the balance needed between inhabitants and natural and cultural local values. In Portugal, other cultural landscape properties listed as World Heritage, had problems finding this balance, such as Sintra and Alto Douro, due to modern urban pressures and climate change impacts (such as fires due to rising temperatures and droughts).

As mentioned by Costa Lobo and Simões Júnior (2012), the preservation of the traditional forms became highly relevant mostly to the urban planning and management levels. The main question is how the urban and architectural regulations are being addressed to protect the cultural landscape heritage. Like in other international cases, it is important to reflect on these rising concerns and to find possible solutions.
The method to address this issue, in the case of Pico island, is through several resources: the historical framework by local sources, the reading of indicators and key-reference documentation, observation, cartography and the recording of cultural landscape; as well as the analysis of architectural and urban regulation in territory planning. Applying scientific methods, through techniques to collect data and to analyse it, will help find answers in a systematic and consistent way when addressing the research problem.

Following, the article presents the evolution of human occupation and its cultural and landscape values. Then, it discusses the regulatory framework currently in place, with particular emphasis on its various scales of analysis, in order to contribute to the management practices of the protected landscape.

\section{THE HUMAN SETTLEMENTS IN PICO}

Before addressing the analysis of Pico's architecture and urbanism, it is important to understand the human settlements in the island. This table presents the evolution of the number of inhabitants in three municipalities.

\begin{tabular}{|lr|r|r|r|r|}
\hline & Year & $\mathbf{1 9 0 0}$ & $\mathbf{1 9 2 0}$ & $\mathbf{1 9 4 0}$ & $\mathbf{1 9 6 0}$ \\
\hline Lajes & & 9371 & 7457 & 8168 & 8156 \\
\hline Madalena & & 8499 & 7256 & 7855 & 8359 \\
\hline São Roque & & 6314 & 5214 & 5400 & 5292 \\
\hline & Total & $\mathbf{2 4 1 8 4}$ & $\mathbf{1 9 9 2 7}$ & $\mathbf{2 1 4 2 3}$ & $\mathbf{2 1 8 0 7}$ \\
\hline
\end{tabular}

\begin{tabular}{|r|r|r|r|r|r|}
\hline $\mathbf{1 9 7 0}$ & $\mathbf{1 9 8 1}$ & $\mathbf{1 9 9 1}$ & $\mathbf{2 0 0 1}$ & $\mathbf{2 0 1 1}$ & $\mathbf{2 0 1 8}$ \\
\hline 6605 & 5828 & 5563 & 5041 & 4711 & 4524 \\
\hline 6860 & 5977 & 5964 & 6136 & 6049 & 5892 \\
\hline 4650 & 3678 & 3675 & 3629 & 3388 & 3271 \\
\hline $\mathbf{1 8 1 1 5}$ & $\mathbf{1 5 4 8 3}$ & $\mathbf{1 5 2 0 2}$ & $\mathbf{1 4 8 0 6}$ & $\mathbf{1 4 1 4 8}$ & $\mathbf{1 3 6 8 7}$ \\
\hline
\end{tabular}

Table 1. Number of inhabitants in the municipalities since the beginning of the 20th century until 2018. Source: Serviço Regional de Estatística dos Açores.

Following the phylloxera infestation and the powdery mildew fungal disease that attacked Pico wineries, the population of Pico island decreased dramatically, as it can be perceived through Table 1. Nonetheless, the average percentage, of around 1.000 inhabitants per decade, is different for each Pico municipality. The oldest village, Lajes do Pico, in the south of the island, and São Roque, in the north side, lost $30 \%$ of the population in the last hundred years, but the island capital, Madalena, only lost a half of it. In this century, the difference to the decades of the 70's and the 80 's was most relevant. This was certainly a consequence from the socioeconomic changes in the country, the end of the Portuguese colonial war in Africa, the transition to the democracy, and the emigration to the main cities in the continent. This is mostly why, the maintenance of traditional characteristics in architecture and urbanism was kept. According to Maciel (2018), that is why these small villages did not change so much during the 20th century. In recent years, it was observed that there was an increase on interventions using foreigner materials and building systems. However, this did not happen in the cultural landscape protected area, as vernacular architecture had to be preserved, due to the World Heritage legislative protection. 


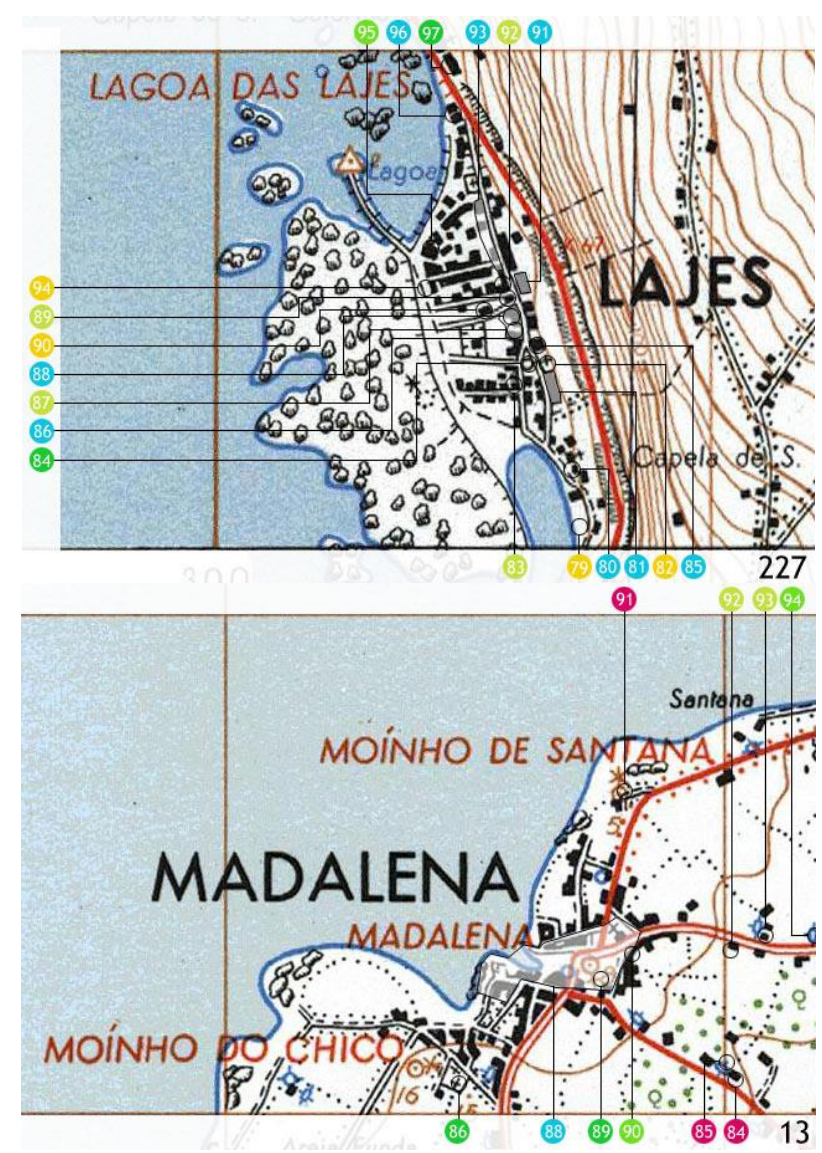

Figure 2. Cartography of Lajes and Madalena villages around 1980. Source: Inventário do Património Imóvel dos Açores.

Figure 2 presents the settlements of Lajes and Madalena, around 1980. The villages were born from the best sites with natural conditions to build a port, for economic sea activities and transport.
They both present a small urban concentration of around 20 hectares. In the case of Lajes, there is impossible direct connections to the hinterland, due to the highly terrain relief. These settlements are an example of the so-called Portuguese urbanism: a main irregular square beside the church and a sequence of small houses along narrow streets, linked to the landscape (Fernandes, 1987; Teixeira, 2015). This linear urban model is frequently developed between two poles: a square for that religious vocation and another one with a civil or administrative function.

Particularly in the case of Lajes, José Manuel Fernandes (1996, p.376) mentioned that the village was "a remarkable urban centre of quality and vernacular expression". Despite its small size, it has an overall image highly valued for the architectural homogeneity of the two-story houses that flank its main street. Concerning the buildings, he underlines that "they result from combinations and recreations of various types, in an innovative melting pot, giving consistency to what can be called Macaronésia Insular House" (ibid.).

In fact, through all the Island, it is possible to find the influence of the whale shipping industry in the built environment. Some of the anonymous buildings were named as a kind of "whaling architecture" - an expression trying to identify the materials and visual memories of the boats in houses and cellars. Marques also expresses that "the restoration of a significant number of the unique vessels, used for recreational and sporting purposes, is a sign of the cultural impact that whale hunting, extinct since 1984, still has among these communities" (2010, p.XIII).

In the north side of Pico, the smaller villages of Cabrito and Lajido, in the municipality of São Roque, present the same type of singularities associated with this vernacular architecture. In the border of the sea, the cellars with the black stones from the volcano were built to keep the wine safe, but the inhabitants lived some kms above in the half slope. Through generations, many families kept this regular moving, respecting the climate and agricultural seasons, as recalled by Amorim (2016).

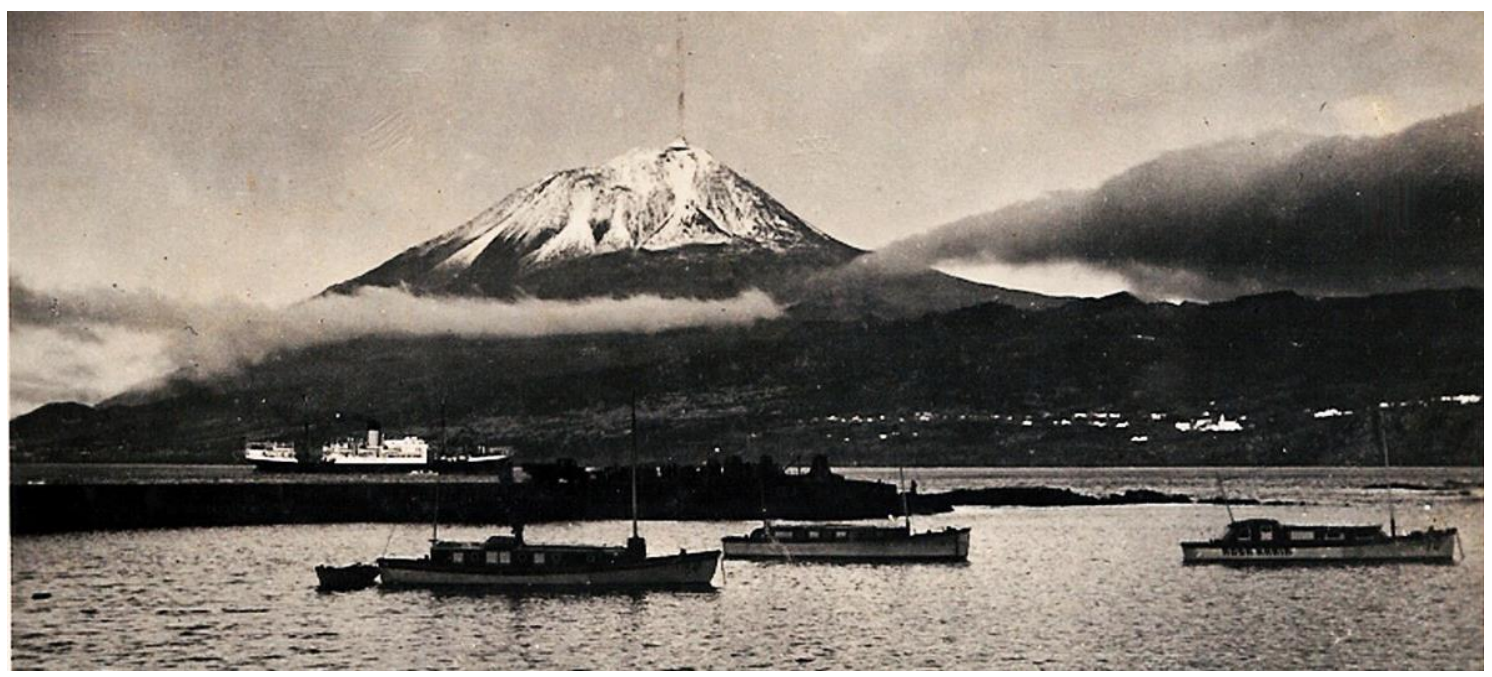

Figure 3. View of the volcano from the Lajes bay. Source: Arquivo de Villa Maria, Terceira, Azores.

The next figure, Figure 4, presents a drawing of Cabrito settlement, where it can be observed the transformation and division of the land in small private plots, as an example of traditional rural settlement, along the ancient pedestrian paths.
The lack of previous design does not mean that some informal regulations were not respected by the population. In fact, each settlement had a religious temple and collective spaces to share the wine, which proves a strong local community solidarity, kept until nowadays, as a particular way of living together. 


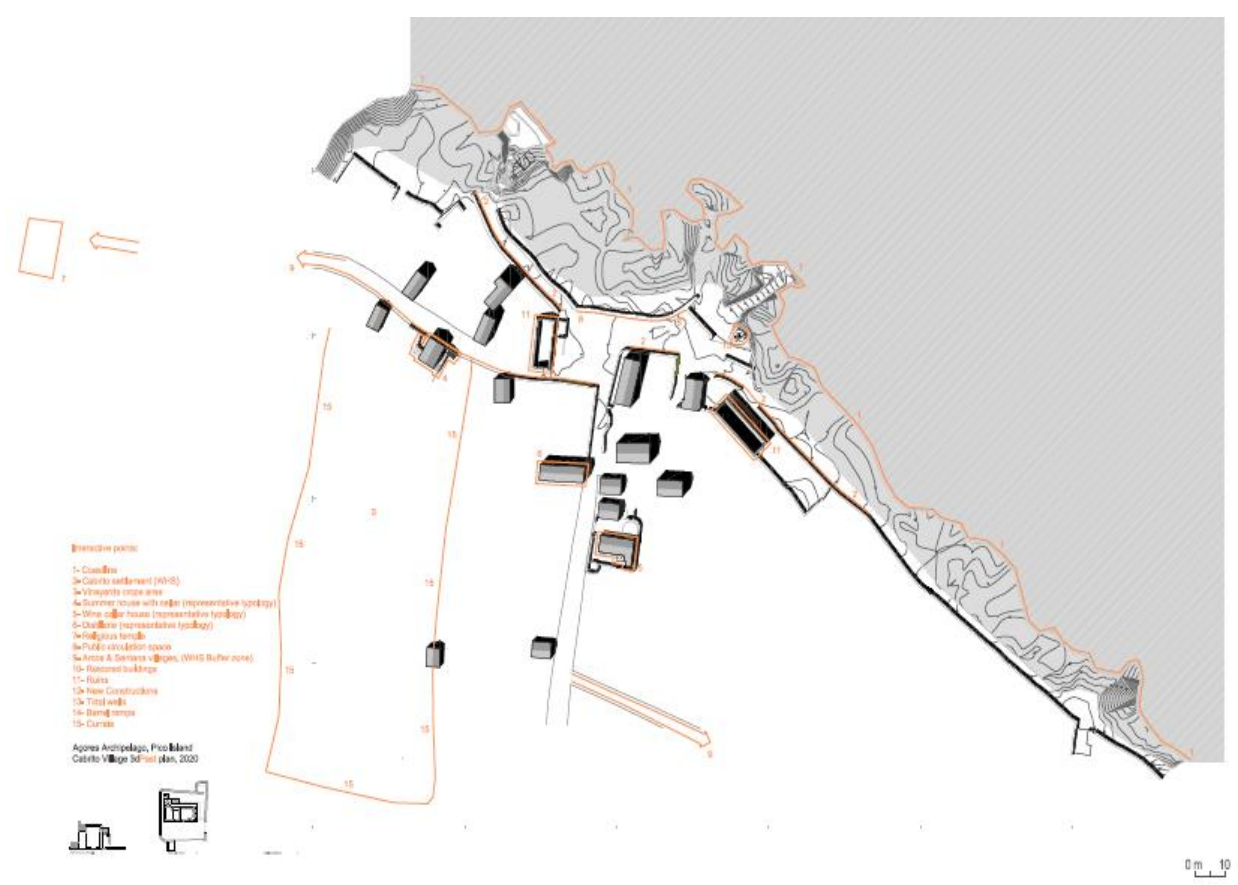

Figure 4. Plan of Cabrito settlement. Source: 3dPast Research project. Ci-ESG, Escola Superior Gallaecia, 2020.

At the end of the 20th century, following the research on "Popular Architecture" in continental Portugal, the National Association of Architects invited several experienced architects to address the identification of the Atlantic Islands traditional characteristics. The results from the archipelago of Azores were possible thanks to a collective work coordinated by João Vieira Caldas, and published by the National Association of Architects. This collected knowledge made a substantial contribution to the preservation of the local architecture main cultural values in Pico Island: an architecture composed of a simple geometry of small isolated volumes, only opened to functional needs, facing challenging weather conditions. Materials would come directly from the island environment (volcanic rock, burnt limestone to create lime plaster, etc.) and the coloured wood would be originated from the shipping industry.

\section{CULTURAL LANDSCAPE}

The 21 countries that compose the World Heritage Committee vote every year, with the technical support of the Advisory Bodies (ICOMOS, IUCN, and ICCROM) for cultural and natural properties to become World Heritage (Correia, 2018). The traditional environment of Pico was recognized in 2004, under the Cultural Landscape category as a World Heritage property. The Outstanding Universal Value that was granted to the property was due to criteria (iii) and (v), and to the preservation of its authenticity, integrity, protection and management. The 987 ha. site of protected land, with almost a double area of "buffer zone", is covered by an extensive system of hand-made viniculture of grape growing (UNESCO-WHC, 2004). This camp of stone walled fields is a testimony to generations of small-scale farmers who, in a hostile environment, created a sustainable living and a much-valued wine. The outstanding vineyard landscape is largely intact and very well preserved, without additions of intrusive modern structures. It includes a network of enclosed stone-walled fields, locally called currais, complemented by a traditional variety of buildings (houses, wine cellars, windmills, churches, warehouses and other traditional structures), pathways, wells, ports and fig trees.
The authenticity that emerges from this World Heritage property reflects an imposing pattern of orderly, long, linear walls running inland from, and parallel to, the rocky Atlantic coastline. It is a unique viniculture landscape that has been evolving since the arrival of the first settlers in the 15th century. The wine production was managed since then, under a regime designed to ensure economic viability and sustainability, as well as to retain the traditional farming techniques. These clusters of black volcano stone walls complete a thousand of small, contiguous and rectangular plots, built to protect crops from wind and salt spray.

The island comprises both areas of abandoned stone-walled enclosures (a relict cultural landscape), and other ones where grape production continues to take place (a continuing, living and working landscape). The expansion of the local wine-based industry, in part as a consequence of World Heritage status, was not considered a threat to the authenticity of the property, as viniculture practices are carried out by individual ownerfarmers without the use of mechanical vine-growing methods.

However, the property is vulnerable to a number of factors that became pressures and can evolve to threats if they are not carefully addressed. This includes mass tourism and the import of stone for re-building, not consistent with local materials. In this case, the property's integrity could be threatened due to the construction of new buildings that are incompatible with the visual integrity required for a World Heritage property. Also, in jeopardy could be the possible future development and expansion of Pico airport, which risks to impact the Outstanding Universal Value (OUV) of the property (Figure 5).

This cultural landscape heritage has been protected and has management requirements, through a system of legislation, plans, and a kind of multi-tiered administrative system. Different mechanisms of protection are in place at the national, regional (island) and municipal levels. Even before, laws to protect both the vine growing areas and the standards of wine production on Pico Island were passed in 1980, 1988, and 1994. In 1996, a wide cultural landscape was classified in 
Pico as Protected Landscape, under the category of typical living landscapes (UNESCO-WHC, 2004). This protected area covered more than the 2004 area that later on, would be listed as World Heritage (with areas beyond the buffer zone).

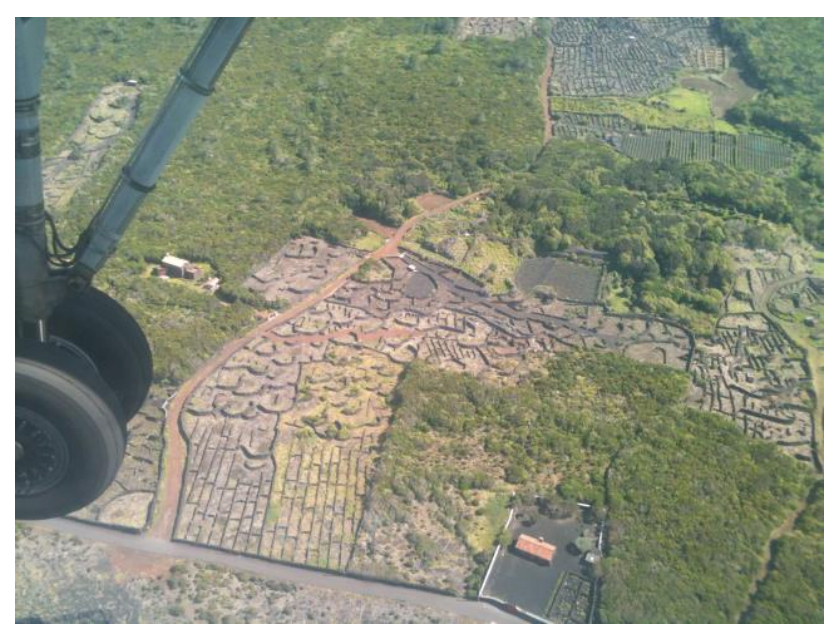

Figure 5. Aerial approach to Pico. Photo by Rui Florentino.

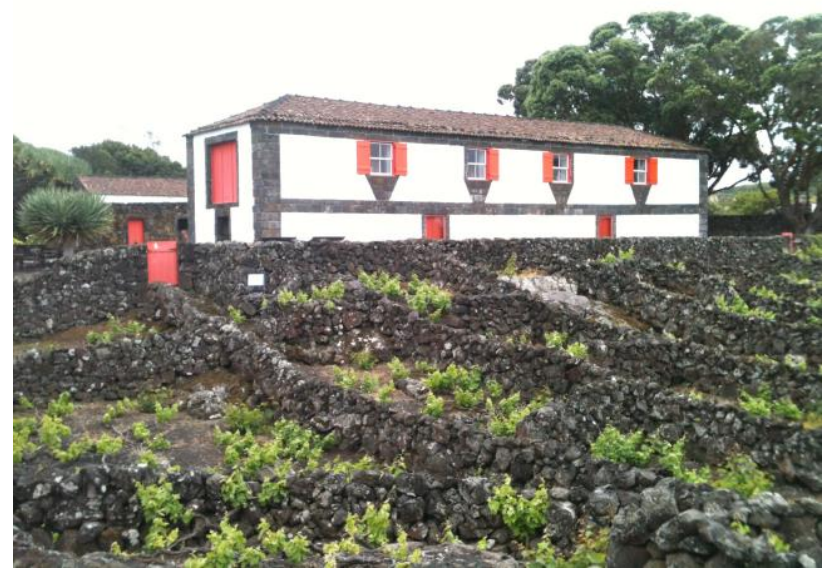

Figure 6. The Wine Museum by the local architect Paulo Gouveia (1939-2009). Photo by Rui Florentino.

Since 2002, the regional government law number 10 provides four levels of protection that includes two zones for stone wallenclosed vineyards (currais - the small lajidos), or broad lava flow fields of Criação Velha and Santa Luzia, which are areas protected for their high-quality wine production. The Territory planning is regularly revised, as municipal plans started being applied due to some protective rules, implemented at the end of 20 th century.

A Technical Committee, appointed by the Azorean government for the Environment, is now responsible for the World Heritage property management. At the regional level, the Pico Island Department of Environment provides scientific expertise, while the municipal authorities of Madalena (for Criação Velha) and São Roque do Pico (for Santa Luzia) exercise planning control according to management regulations, relating to vine growing methods, local roads, and buildings.

The investments in viticulture traditional practices are being supported by the regional government and the public examples of heritage interventions to protect the site were introduced with high quality concerns, carefully respecting the World Heritage values (Figure 6). The site of Pico was recognized again in 2018, at national level, with the Landscape award, concerning Portuguese contribution to the European Convention Landscape awards.

The signature of the Azorean architect Paulo Gouveia in the main cultural buildings of the Island was also awarded in several occasions. Furthermore, SAMI architects' intervention in some of Pico's vernacular buildings, introduced contemporary uses through private investments, respecting, as much as possible, the original structures. SAMI were also the authors of the Wine Landscape Interpretation Centre, with the restoration of an older cellar in Lajido (2009). This contemporary intervention respecting the regional language has been a singular good practice in other Atlantic Islands. This was also the case of César Manrique well-known works in Lanzarote, Canarias islands in Spain.

\section{SITE MANAGEMENT AND URBAN REGULATIONS}

However, some concerns were raised on how the public bodies would proceed in Pico, concerning the spatial regulations, in order to protect the classified area? In 2006 the POPPVIP Plan (Plano de Ordenamento da Paisagem Protegida de Interesse Regional da Cultura da Vinha da Ilha do Pico) was approved, a special Plan designed for this purpose and approved by the Azorean Regional Government. The plan is complemented by the management plan, which established the program for investments and public actions in the protected area. The POPPVIP plan is considered "special" by the Portuguese law, because it affects directly the land-use and the local regulations, being mandatory for all the projects and private interventions, as the municipal plans are. These ones were previously approved, but according to the 2014 national law for territorial management, their revision should consider the regulations of this special plan for the protected area.

The analysis focuses in the municipalities of Madalena and São Roque do Pico, starting with the Director Plans (PDM). In the first one, published in 2005, the World Heritage area was considered a "natural and cultural space". A special mention is dedicated to the preservation of windmills and whale watching spots, as well as the control of visual corridors, forbidding intersections with it, respecting therefore, visual integrity. In the case of São Roque PDM, the match with the classified wine landscape heritage is not so direct, because it was approved in 1999, and published a year after. The São Roque PDM considers the protected area as natural and cultural landscape, respecting the jurisdiction of the regional department, in spite of considering that the windmills buffer zone is only of 100 meters. Also, the cartography analysis shows some overlap between the preservation of the agricultural area and the admitted urban area in the municipal plan (Figure 7).

The monitoring of the POPPVIP, the 'Land Management Plan of the Protected Landscape of Pico Vineyard Culture' is being addressed by the Regional Directorate for the Environment (Rocha, 2013), with the collaboration of the technical office for the management of the World Heritage area, established in 2011. That document marks the analysis between the different regional and municipal plans and the public support for the restoration and maintenance of the traditional wine agriculture, who reaches more than $600.000 €$, and almost 140 productive hectares in 2012. 


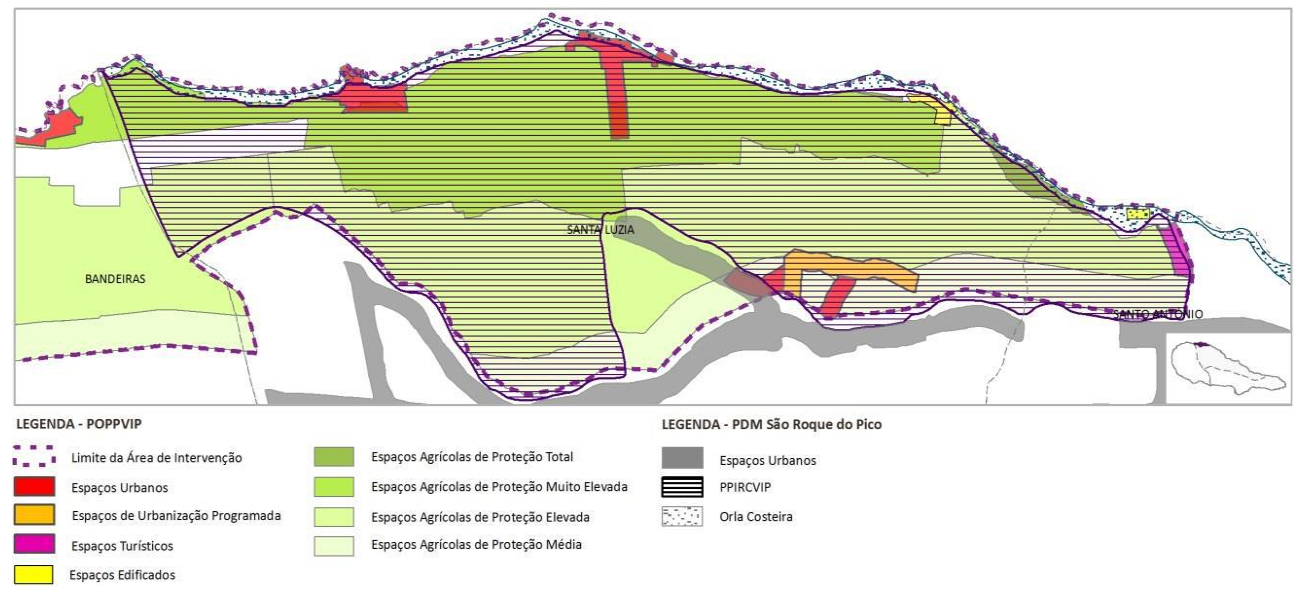

Figure 7. Cartography analysis between the special Protection Plan and the São Roque Municipal Plan. Source: Rocha (2013).
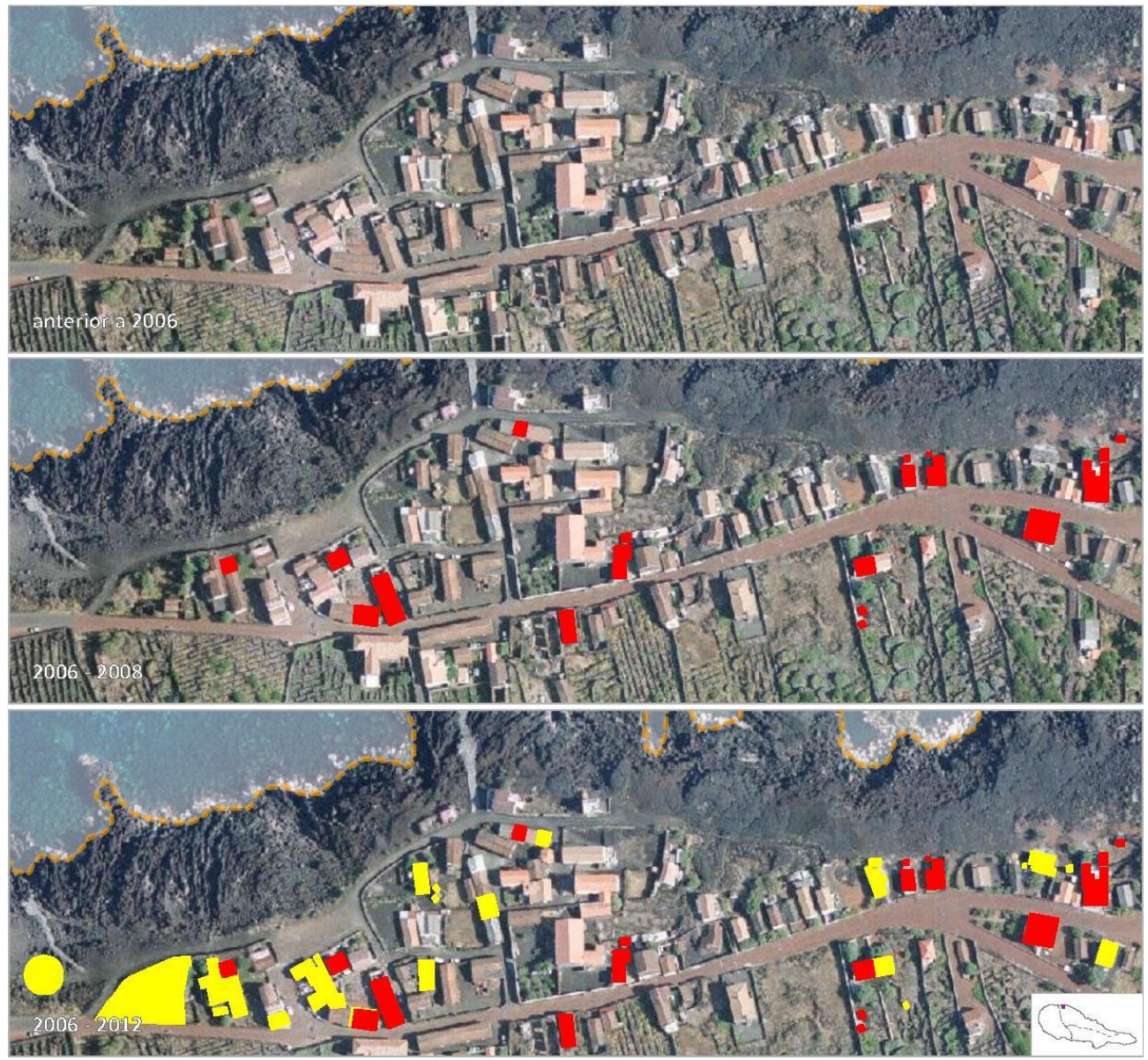

LEGENDA

-7. Área de intervenção do poppy

Pedidos de parecer e pedidos de apoio para eliminaç̃o de dissonâncias arquitetónicas entre 2006 e 2008

Pedidos de parecer e pedidos de apoio para eliminação de dissonâncias arquitetónicas entre $2009 \mathrm{e} 2012$

Figure 8. Processes for architectonic dissonances correction between 2006 and 2012 in Lajido. Source: Rocha (2013).

Furthermore, it was observed in the assessment report (Rocha, 2013) that the financial support for the preservation of cultural heritage and for the correction of architectonic dissonances in the protected area goes up to $50 \%$ maximum of the total costs. This value also increased since 2005 , concentrated in traditional settlements as Lajido, in the Figure 8. The POPPVIP and the Azores Government regional support are therefore the principal instruments to protect the Pico Island vernacular architecture and its traditional urbanism.
The Plan was revised in 2014 according to the Azorean law for Spatial Planning, and reflects the present regulations for the projects. Regarding the vernacular wine agriculture traditional systems, it is only possible to address their conservation and it is forbidden to remove it or destroy it. In the preservation of existing buildings and on their adaptation to new uses, the law also imposes that the design should respect the traditional elements, like typologies, dimensions, materials and colours, following several specific urban parameters. The restrictions are 
particularly mentioned for all the small urban settlements in the high and medium levels of protection. The agricultural spaces have also different zones of preservation and the technical office for the World Heritage property is responsible for all the processes, the management and the implementation of the plan.

\section{CONCLUSIONS}

Vernacular architecture and the small settlements of Pico were very well preserved throughout the years due to the geological nature of the Island and its socioeconomic circumstances. The insularity and the decrease on the number of inhabitants, halted the modern process of industrialization, a trend that affects in general, the landscapes of developed countries.

Since the classification of the property as Word Heritage, a new phase of development is taking place, based on traditional agricultural practices and architectural regulations. The 'Land Management Plan of the Protected Landscape of Pico Vineyard Culture' (POPPVIP) views the property as a living, working landscape that is maintained and protected by sustaining the area's distinctive wine-making traditions and thereby preserving the complex field patterns and associated structures and houses.

The purpose of this Plan is to further promote the maintenance and recovery of the vineyard landscape, turning it the driver for the Pico Island development (POPPVIP, 2014). The Plan allowed the Regional Government to adopt measures to impose planning constraints on new buildings, use appropriate local building materials, reconstruct ruins, revitalise abandoned vineyards, remove invasive plants, and guarantee the revitalisation of the landscape through the progressive increase of cultivated vines under traditional methods.

There are threats and challenges that need to be addressed, as seen in the previous analysis, especially relating overlaps of different spatial regulations, in the most vulnerable areas for tourism. In the Municipal Plans following revisions, to become more comprehensive and effective, it is then important to use the reports assessment (Rocha, 2013), the support carried out by the Regional Directorate for the Environment and of course the monitoring of the World Heritage technical office.

This paper confirms that sustaining the Landscape of the Pico Island Vineyard Culture in the long-term will require ongoing coordination between the different levels of government in partnership with the local communities and land owners. To face these issues, some tools of new technologies are already being implemented by the public authorities, as the geographic information system, on which the focus is to maintain a traditional environment of architecture and urban places, through territory regulations that can be considered as good practices for the management of other World Heritage properties.

Finally, the virtual products of the $3 \mathrm{dPast}$ research project will value the significance of the liveable cultural property, contributing to the enhancement of its Outstanding Universal Value. In fact, the future protection of the 500-year old vineyard landscape will rely on continuing, effective, and realistic partnerships that not only strengths the international dissemination of good practices but that also supports small land-owners to continue with their sustainable wine production, preserving traditional viniculture practices.

\section{ACKNOWLEDGEMENTS}

This paper is the result of the research project 3D Past - "Living \& virtual visiting European World Heritage" [Grant Agreement Ref No570729-CREA-1-2016-1-PT-CULT-COOP1], which was co-funded by the European Union, under the programme Creative Europe (2016-2020).

The authors would like also to thank the Architects Delfim Marques and Jorge Santos Silva, for their valuable comments, which contributed for the enhancement of the paper.

\section{REFERENCES}

Amorim, M.A., 2016: O Pico. A abordagem de uma ilha. Vol. I - As Famílias. Tomo IX - As famílias de Santa Luzia nos finais do século XIX. Desafios da Montanha, CITCEM, Porto.

Correia, M., 2018: Avaliação de Sítios Culturais Património Mundial, In Porto Forum: Heritage, City, Architecture. CEAUFAUP, Porto, p.126-144

Costa Lobo, M., Simões Júnior, J.G., 2012: Urbanismo de colina: uma tradição luso-brasileira. IST Press, Lisboa, Universidade Presbiteriana Mackenzie, São Paulo.

Fernandes, J.M., 1987: O lugar da cidade portuguesa. A Cidade em Portugal: onde se vive. Povos e Culturas, 2. Universidade Católica Portuguesa, Lisboa.

Fernandes, J.M., 1996: Cidades e casas da Macaronésia. FAUP Publicações, Porto.

Macedo, A., 1981: História das Quatro Ilhas que formam o Distrito da Horta. Reimpressão Fac-similada da edição de 1871. Secretaria Regional de Educação e Cultura dos Açores.

Maciel, M., 2018: Paisagem da Vinha do Pico - antes e depois da Filoxera. Perspectiva Económica e Social. Alto Douro e Pico, paisagens culturais vinhateiras património mundial em perspectiva multifocal: experimentação comparada. CITCEM, Porto.

Marques, D., 2010: A Arquitectura baleeira na cidade da Horta e na vila das Lajes do Pico. Um contributo para o seu estudo. Universidade Lusíada, Lisboa.

Nemésio, V., 1944: Mau tempo no Canal. Bertrand, Lisboa. POPPVIP, 2014: Decreto Regulamentar Regional $n .^{\circ} 7 / 2014 / A$, de 6 de maio. Azores Government.

Rocha, M. (coord.), 2013: Plano de Ordenamento da Paisagem Protegida da Cultura da Vinha da Ilha do Pico. $1^{\circ}$ Relatório de Avaliação 2006-2012. Direcção Regional do Ambiente dos Açores.

Teixeira, M., 2015: A forma da cidade de origem portuguesa. Editora UNESP, São Paulo.

UNESCO-WHC, 2004: Landscape of the Pico Island Vineyard Culture. Available at: https://whc.unesco.org/en/list/1117/ 